\title{
Deep sequencing reveals the complex and coordinated transcriptional regulation of genes related to grain quality in rice cultivars
}

\author{
RC Venu ${ }^{1 \dagger}$, MV Sreerekha ${ }^{1 \dagger}$, Kan Nobuta ${ }^{2}$, André Beló ${ }^{2}$, Yuese Ning ${ }^{4}$, Gynheung $\mathrm{An}^{3}$, Blake C Meyers ${ }^{2}$ and \\ Guo-Liang Wang ${ }^{1,4^{*}}$
}

\begin{abstract}
Background: Milling yield and eating quality are two important grain quality traits in rice. To identify the genes involved in these two traits, we performed a deep transcriptional analysis of developing seeds using both massively parallel signature sequencing (MPSS) and sequencing-by-synthesis (SBS). Five MPSS and five SBS libraries were constructed from 6-day-old developing seeds of Cypress (high milling yield), LaGrue (low milling yield), Ilpumbyeo (high eating quality), YR15965 (low eating quality), and Nipponbare (control).

Results: The transcriptomes revealed by MPSS and SBS had a high correlation co-efficient (0.81 to 0.90), and about $70 \%$ of the transcripts were commonly identified in both types of the libraries. SBS, however, identified 30\% more transcripts than MPSS. Among the highly expressed genes in Cypress and llpumbyeo, over 100 conserved cis regulatory elements were identified. Numerous specifically expressed transcription factor (TF) genes were identified in Cypress (282), LaGrue (312), Ilpumbyeo (363), YR15965 (260), and Nipponbare (357). Many key grain quality-related genes (i.e., genes involved in starch metabolism, aspartate amino acid metabolism, storage and allergenic protein synthesis, and seed maturation) that were expressed at high levels underwent alternative splicing and produced antisense transcripts either in Cypress or Ilpumbyeo. Further, a time course RT-PCR analysis confirmed a higher expression level of genes involved in starch metabolism such as those encoding ADP glucose pyrophosphorylase (AGPase) and granule bound starch synthase I (GBSS I) in Cypress than that in LaGrue during early seed development.

Conclusion: This study represents the most comprehensive analysis of the developing seed transcriptome of rice available to date. Using two high throughput sequencing methods, we identified many differentially expressed genes that may affect milling yield or eating quality in rice. Many of the identified genes are involved in the biosynthesis of starch, aspartate family amino acids, and storage proteins. Some of the differentially expressed genes could be useful for the development of molecular markers if they are located in a known QTL region for milling yield or eating quality in the rice genome. Therefore, our comprehensive and deep survey of the developing seed transcriptome in five rice cultivars has provided a rich genomic resource for further elucidating the molecular basis of grain quality in rice.
\end{abstract}

\section{Background}

Rice is the staple food crop of more than $50 \%$ of the global population, and development of high yielding and high quality rice varieties is essential. Rice grain quality is assessed by its appearance and by its milling, cooking, eating, and nutritional quality [1-3]. Milling yield (the

\footnotetext{
* Correspondence: wang.620@osu.edu

† Contributed equally

'Department of Plant Pathology, The Ohio State University, Columbus OH43210, USA

Full list of author information is available at the end of the article
}

percentage of whole grain remaining after removal of the hulls and bran layers from paddy rice) is a very important characteristic that greatly affects profits for rice farmers. Milling yield or milling efficiency is determined based on the quality of the paddy rice, the milling equipment used and the skill of the mill operator. Milling yield is influenced by grain hardness, chalky area of the grain, grain size and shape, depth of surface ridges, bran thickness, and milling efficiency [4-7]. Agronomic and field managements also affect grain breakage during milling $[5,8,9]$. Rice eating quality is important because it determines the
C Biomed Central

() 2011 Venu et al; licensee BioMed Central Ltd. This is an Open Access article distributed under the terms of the Creative Commons Attribution License (http://creativecommons.org/licenses/by/2.0), which permits unrestricted use, distribution, and reproduction in any medium, provided the original work is properly cited. 
price of rice in the market. Eating quality is determined by water, protein, starch, and fat content [10-14]. Eating quality is negatively correlated with protein content, stickiness, and hardness of rice $[10,11]$. The main factors affecting both eating and cooking quality of rice are amylose content, gel consistency and gelatinization temperature $[12,13,15,16]$. Cooked rice with high amylose content is flaky, dry, hard and non-sticky while rice with low amylose content is sticky, moist, tender and glossy [12,13]. Developing cultivars with high milling yield and eating quality have been the main objectives in rice breeding programs in the last few decades.

Milling yield and eating quality are complex traits controlled by quantitative trait loci (QTLs) [17]. In the last several years, many QTLs for eating quality have been mapped in the rice genome. For example, using chromosome segment substitution lines (CSSLs), Wan et al. [18] identified a total of 25 QTLs for nine eating quality traits. Many QTLs affecting different quality traits are mapped in the same chromosomal regions. Six QTLs are non-environment-specific and could be used for marker-assisted selection in rice quality improvement. Recently, Hao et al. [19] constructed 154 CSSLs for QTL mapping of quality traits. In that study, 10 QTLs for rice appearance traits and eight QTLs concerned with physico-chemical traits were detected. QTLs related to glossiness of cooked rice were identified in different genomic regions in Ilpumbyeo, a high grain quality rice in Korea [20]. The amylose content of rice is governed by the waxy (Wx) locus and mapped to chromosome 6 [21-23]. In contrast to the advances in genetic analysis of eating quality, less progress has been made on the genetic analysis of milling quality because the trait has low heritability and is sensitive to environmental factors [24,25]. Another challenge for milling yield analysis is that many mapping populations for milling yield had varied kernel shape among the individual lines and heterogeneity in grain dimensions confounds the assessment of genetic effects [9,24,26-31]. Recently, a mapping study identified six QTLs responsible for head rice (milling) yield using recombinant inbred lines (RILs) derived from crosses of common parent Cypress (high milling) with RT0034 (low milling) and LaGrue (low milling) [9].

The molecular and biochemical basis of grain quality in cereals have been studied in the last decade, and the biochemical processes and many participating genes in the synthesis of starch [32-34], storage proteins [35-39], and lysine within the aspartate family amino acid pathway [40] have been characterized in rice and other cereals. However, how the expression of these genes is coordinated and regulated during grain filling is still poorly understood. Recently, Tian et al. [41] demonstrated that starch synthesis-related genes form a fine network to control eating and cooking qualities by regulating amylose content, gel consistency, and/or gelatinization temperature, and through genetic modification of any of these starch synthesis-related genes, eating and cooking quality can be improved in rice. The expression of 44 genes participating in three pathways (the synthesis of starch, storage proteins, and lysine) during rice grain filling were examined by RT-PCR in the maternal line 93-11 and in the super-hybrid rice line Liang-You-Pei-Jiu (LYP9) [3]. The analysis revealed diverse yet coordinated expression profiles of genes involved in the three pathways in developing seeds. These unique expression patterns of the quality-related genes may influence the final composition and property of starch, protein, and lysine synthesis in rice seeds.

Tools for whole-genome expression analysis like microarrays, serial analysis of gene expression (SAGE) and massively parallel signature sequencing (MPSS) have been widely used for transcriptome analysis in plants in last 10 years [42]. The sequencing-by-synthesis (SBS) secondgeneration sequencing method has been recently used for transcriptome analysis in many organisms because of its low cost and large sequencing output [43]. In this study, we used both MPSS and SBS to analyze the transcriptome of the developing rice seeds in five cultivars that differed in milling yield and eating quality. Many differentially expressed novel transcripts and genes involved in the biosynthesis of starch, aspartate family amino acids, and storage proteins were identified. Promoter analysis revealed the presence of hundreds of novel conserved patterns of cis regulatory elements in the up-regulated genes and putative co-expressed genes in the rice cultivars with high milling yield and good eating quality. Our comprehensive and deep survey of the developing seed transcriptome in five rice cultivars has provided an excellent starting material for further elucidating the molecular and biochemical basis of milling and eating quality in rice.

\section{Results}

Characteristics of the MPSS and SBS libraries and their matching to the rice genome and to EST and full-length cDNA databases

Both MPSS and SBS tags are short cDNA tags or digital gene expression tags, which are mainly derived from the 3 ' regions of a transcript [44]. About 1.0 to 1.3 million 17-base MPSS signatures and about 2.0 to 4.0 million 20base SBS signatures were obtained in the 10 libraries (Table 1). These signatures were clustered and then processed with reliability and significance filters as described by Meyers et al. [45] (Additional File 1). For comparison of the expression levels across the libraries, the frequency of signatures in the individual libraries was normalized to one million (transcripts per million or TPM) [45]. The number of distinct signatures ranged from 12,000 to 
Table 1 Characteristics of the MPSS and SBS libraries of developing rice seeds

\begin{tabular}{|c|c|c|c|c|c|c|c|c|c|c|}
\hline \multirow[t]{2}{*}{ Classification } & \multicolumn{2}{|c|}{ Cypress (PSC) } & \multicolumn{2}{|c|}{ LaGrue (PSL) } & \multicolumn{2}{|c|}{ Ilpumbyeo (PSI) } & \multicolumn{2}{|c|}{ YR15965 (PSY) } & \multicolumn{2}{|c|}{ Nipponbare (PSN) } \\
\hline & MPSS & SBS & MPSS & SBS & MPSS & SBS & MPSS & SBS & MPSS & SBS \\
\hline Number of reads & $1,266,713$ & $3,718,464$ & $1,082,099$ & $2,326,663$ & $1,201,584$ & $3,293,394$ & $1,190,250$ & $2,634,791$ & $1,207,914$ & $4,110,241$ \\
\hline Distinct signatures & 12,660 & 103,741 & 18,297 & 165,129 & 17,783 & 83,071 & 12,379 & 77,023 & 16,499 & 104,531 \\
\hline Significant signatures & 10,099 & 30,571 & 14,253 & 36,335 & 13,971 & 25,915 & 10,402 & 23,302 & 13,116 & 34,165 \\
\hline Non-significant signatures & 2,561 & 73,170 & 4,044 & 128,794 & 3,812 & 57,156 & 1,977 & 53,721 & 3,383 & 70,366 \\
\hline 1-100 TPM & 10,705 & 101,187 & 16,280 & 161,929 & 15,605 & 80,069 & 10,449 & 74,564 & 14,486 & 101,894 \\
\hline 101-1,000 TPM & 1,783 & 2,312 & 1,827 & 2,896 & 1,985 & 2,704 & 1,741 & 2,226 & 1,815 & 2,389 \\
\hline 1,001-10,000 TPM & 157 & 228 & 177 & 290 & 183 & 284 & 176 & 218 & 186 & 234 \\
\hline$>10,000$ TPM & 15 & 14 & 13 & 14 & 10 & 14 & 13 & 15 & 12 & 14 \\
\hline $\begin{array}{l}\text { Total signatures matched to the } \\
\text { Nipponbare genome }\end{array}$ & 10,940 & 22,872 & 15,813 & 17,521 & 15,276 & 20,032 & 10,678 & 18,313 & 14,378 & 28,118 \\
\hline $\begin{array}{l}\text { Significant signatures matched to the } \\
\text { Nipponbare genome }\end{array}$ & $\begin{array}{l}8,855 \\
(80.9 \%)\end{array}$ & $\begin{array}{l}21,582 \\
(94.3 \%)\end{array}$ & $\begin{array}{l}12,534 \\
(79.2 \%)\end{array}$ & $\begin{array}{l}15,514 \\
(88.5 \%)\end{array}$ & $\begin{array}{l}12,313 \\
(80.6 \%)\end{array}$ & $\begin{array}{l}19,000 \\
(94.8 \%)\end{array}$ & $\begin{array}{l}9,118 \\
(85.3 \%)\end{array}$ & $\begin{array}{l}17,477 \\
(95.4 \%)\end{array}$ & $\begin{array}{l}11,622 \\
(80.8 \%)\end{array}$ & $\begin{array}{l}25,777 \\
(91.6 \%)\end{array}$ \\
\hline $\begin{array}{l}\text { Significant signatures specifically } \\
\text { identified by either MPSS or SBS }\end{array}$ & 2,359 & 22,831 & 3,869 & 25,951 & 5,219 & 17,163 & 3,216 & 16,116 & 3,669 & 24,718 \\
\hline $\begin{array}{l}\text { Significant signatures identified by both } \\
\text { MPSS and SBS }\end{array}$ & $7,740(77 \%$ & \% overlap) & $\begin{array}{l}10,384(73 \\
\text { overlap) }\end{array}$ & & $8,752(62 \%$ & \% overlap) & $7,186(70 \%$ & \% overlap) & $9,447(729$ & \% overlap) \\
\hline
\end{tabular}

18,000 in the MPSS libraries and from 77,000 to 165,000 in the SBS libraries. The SBS libraries contained two to three times more significant signatures $(\geq 4$ TPM) than the MPSS libraries. About 79 to $85 \%$ of the MPSS and 89 to $95 \%$ of the SBS significant signatures matched to the japonica (Nipponbare) genomic sequence (Table 1). The significant MPSS and SBS signatures from all five libraries were classified into seven classes based on their location on the annotated genes according to the method previously described by Meyers et al. [45] (Additional File 2).

\section{Correlation of the transcriptomic results generated by the MPSS and SBS technologies}

From 62 to 77\% of the significant signatures overlapped between the MPSS and SBS libraries (Table 1). Further, we used all the significant signatures in the MPSS and SBS libraries of the same cultivar for Pearson correlation coefficient analysis. The correlation coefficient was low when unfiltered MPSS and SBS data were used (Table 2). Removal of a small fraction of outliers $(3-8,<0.001 \%$ of the signatures) increased the correlation coefficient significantly in all five libraries (Table 2). For example, the correlation coefficient between the two YR15965 libraries was increased from 0.58 to 0.90 after removal of only four of 5,757 signatures.

Expression patterns of grain quality-related genes in the cultivars with high milling yield and good eating quality Data mining of the TIGR rice annotated genes (pseudomolecules version 5) identified 338 grain quality-related genes belonging to starch biosynthesis and degradation, seed storage protein synthesis (glutelin, globulin, and prolamins), seed maturation, seed allergen synthesis, seed development, and biosynthesis and degradation of aspartate family amino acids (aspartate, asparagine, threonine, isoleucine, methionine, and lysine). We examined the expression level of these genes in developing rice seeds of the five cultivars (Additional File 3). In both SBS and MPSS libraries, a total of 419 (16 grain-related genes) and 168 genes (3 grain-related genes) were $\geq 5$-fold up- and down-regulated, respectively, in Cypress relative to both LaGrue and Nipponbare (Table 3). Similarly, 518 (8 grainrelated genes) and 106 genes (4 grain-related genes) were $\geq 5$-fold up- and down-regulated, respectively, in Ilpumbyeo relative to both YR15965 and Nipponbare (Table 3). The number of 5-fold up- and down-regulated antisense genes, genes with antisense transcripts, and genes encoding transcription factors (TFs) in Cypress (compared to both LaGrue and Nipponbare) and Ilpumbyeo (compared to both YR15965 and Nipponbare) are also listed in Table 3.

\section{Genes involved in starch metabolism}

Many genes involved in starch metabolism showed similar expression patterns in both SBS and MPSS libraries (Table 4 and Additional File 4A). For example, the genes encoding 1,4- $\alpha$-glucan branching enzyme (Os02g32660), limit dextrinase (Os04g08270), 1,4- $\alpha$-glucan branching enzyme (Os06g51084), and $\alpha$-amylase (Os09g29404) were 5-fold up-regulated in Cypress compared to LaGrue and Nipponbare in both SBS and MPSS libraries (Table 4).

Interestingly, we found that genes encoding enzymes involved in the biosynthesis of starch underwent alternative splicing (Figure 1). For example, genes involved in the breakdown of long linear glucan leading to $\beta$-Dglucose-6-phosphate (Os03g55090 encoding phosphorylase and Os03g50480 encoding phosphoglucomutase) 
Table 2 Correlation of the transcriptome results obtained by the MPSS and SBS technologies

\begin{tabular}{lll}
\hline Cultivar & $\begin{array}{l}\text { Correlation coefficient using } \\
\text { all significant signatures* }\end{array}$ & $\begin{array}{l}\text { Correlation coefficient after } \\
\text { removing few outliers }\end{array}$ \\
\hline Cypress & 0.61 & 0.85 (removal of 3 out of 5,803 signatures) \\
LaGrue & 0.49 & 0.83 (removal of 6 out of 6,028 signatures) \\
Nipponbare & 0.53 & 0.87 (removal of 4 out of 7,815 signatures) \\
Ilpumbyeo & 0.39 & 0.81 (removal of 8 out of 6,985 signatures) \\
YR15965 & 0.58 & 0.90 (removal of 4 out of 5,757 signatures) \\
\hline
\end{tabular}

* Only genome matched significant signatures were used.

underwent alternative splicing in Ilpumbyeo and Cypress (Additional File 4A, 4B, 4C). Similarly, the genes encoding the $\alpha$-amylases (Os09g29404/Os04g 08270/Os04g33040/Os01g51754) and 1-4 $\alpha$-glucan branching enzyme (Os06g51084) involved in the breakdown of short linear glucan leading to $\beta$-D-glucose underwent alternative splicing in Ilpumbyeo and Cypress (Additional File 4A, 4B, 4C). Some of the 5fold up-regulated genes identified by either MPSS or SBS also had alternative splicing forms, and these included genes encoding glucose-1-phosphate adenylyltransferase large subunit 1 (also called AGPase) (Os01g44220) and 1,4- $\alpha$-glucan branching enzyme (Os06g51084). Similarly, some of the 5-fold down-regulated genes identified by either MPSS or SBS produced alternative splicing forms, and these included genes encoding 1,4- $\alpha$-glucan branching enzyme (Os06g51084) and phosphoglucomutase (Os03g50480) (Additional File $4 \mathrm{~A}, 4 \mathrm{~B}, 4 \mathrm{C})$. These results showed the complexity of the transcription of quality-related genes in developing rice seeds.

For validation of the MPSS data, two starch biosynthesis-related genes that showed differential expression in the grain libraries were selected for strand specific RTPCR. These two genes encode AGPase (AK073146) and GBSS I (AK070431). Total RNA was isolated from the developing seeds of Cypress, LaGrue, Ilpumbyeo, YR15965 and Nipponbare at 3, 6, 9, 12 and 15 DAF (days after flowering). A time-course study of the
AGPase and GBSS I genes indicated that expression levels were higher in the high milling Cypress than in the low milling LaGrue in the early stages (6 and 9 DAF) of seed development (Figure 2).

\section{Genes encoding essential amino acids}

The aspartate family pathway consists of five amino acids (asparagine, aspartate, lysine, methionine, and threonine), and is catalysed primarily by the enzymes aspartate kinase (AK) and dihydrodipicolinate synthase (DHPS). The regulatory network of the genes involved in the biosynthesis and degradation of aspartate family amino acids is plotted in Additional File 5. The genes involved in the metabolism of the aspartate family amino acids with 5fold up- or down-regulation in Cypress and Ilpumbyeo compared to their controls (LaGrue, YR15965, and Nipponbare) are listed in Additional File 4A, 4B, 4C, and Additional File 5). Some of the important genes for amino acid biosynthesis showed similar expression patterns in both MPSS and SBS libraries (Table 4 and Additional File 4A, 4B, 4C). For example, the genes encoding aspartate transaminase (Os01g55540), methionine adenosyltransferase (Os01g22010), and acetolactate synthase (Os03g21080) were 5-fold up-regulated in Ilpumbyeo compared to YR15965 and Nipponbare in both SBS and MPSS libraries. In contrast, some of the genes involved in aspartate family amino acid biosynthesis were downregulated, including those encoding threonine synthase (Os01g49890), aspartate kinase (Os03g63330), and malate dehydrogenase (Os10g33800) (Additional File 4A,

Table 3 The number of over five fold up- and down-regulated genes in Cypress in comparison to LaGrue and Nipponbare and in Ilpumbyeo in comparison to YR15965 and Nipponbare

\begin{tabular}{|c|c|c|c|c|c|c|}
\hline \multirow[t]{2}{*}{ Classification of genes } & \multicolumn{3}{|l|}{ Cypress } & \multicolumn{3}{|c|}{ Ilpumbyeo } \\
\hline & MPSS & SBS & Common & MPSS & SBS & Common \\
\hline Total number of up-regulated genes & $1536(44)^{*}$ & $4,030(70)$ & $419(16)$ & $2,396(39)$ & $3,339(50)$ & $518(8)$ \\
\hline Total number of down regulated genes & $1409(33)$ & $1,373(14)$ & $168(3)$ & $514(11)$ & $2,119(47)$ & $106(4)$ \\
\hline Total number of up-regulated antisense genes & $164(12)$ & $1,266(32)$ & $23(5)$ & $256(7)$ & $1196(28)$ & $32(1)$ \\
\hline Total number of down regulated antisense genes & $53(7)$ & $330(4)$ & $6(0)$ & $22(5)$ & $372(17)$ & $3(1)$ \\
\hline Total number of up-regulated genes with alternate transcripts & 174 & 382 & 3 & 322 & 305 & 9 \\
\hline Total number of down regulated genes with alternate transcripts & 131 & 95 & 2 & 57 & 195 & 2 \\
\hline Total number of up-regulated transcription factor genes & 125 & 273 & 37 & 182 & 235 & 14 \\
\hline Total number of down regulated transcription factor genes & 102 & 90 & 50 & 34 & 51 & 5 \\
\hline
\end{tabular}

*Inside parenthesis is the number of grain quality-related genes. 
Table 4 List of grain quality genes with similar expression patterns in both SBS and MPSS libraries and up-regulated over five fold in Cypress (in comparison to LaGrue and Nipponbare) and in Ilpumbyeo (in comparison to YR15965 and Nipponbare)

\begin{tabular}{|c|c|c|c|c|c|c|c|c|c|}
\hline $\begin{array}{l}\text { Up- } \\
\text { regulated } \\
\text { in Cypress }\end{array}$ & Family & $\begin{array}{l}\text { TIGR Gene } \\
\text { ID }\end{array}$ & TIGR gene name & MPSS signature & SBS signature & $\begin{array}{l}\text { MPSS } \\
\text { Ratio } \\
\text { PSC/PSL }\end{array}$ & $\begin{array}{l}\text { MPSS } \\
\text { Ratio } \\
\text { PSC/PSN }\end{array}$ & $\begin{array}{l}\text { SBS Ratio } \\
\text { PSC01/ } \\
\text { PSL01 }\end{array}$ & $\begin{array}{l}\text { SBS Ratio } \\
\text { PSC01/ } \\
\text { PLN02 }\end{array}$ \\
\hline & Starch synthesis and degradation & Os04g08270 & $\begin{array}{l}\text { Limit dextrinase, } \\
\text { putative, expressed or } \\
\text { alpha-amylase }\end{array}$ & GATCAGATACTCCTCAC & GATCAAATCTGAACCCATCA & 49 & 16.3 & 8 & 8 \\
\hline & Starch degradation & Os09g29404 & Alpha-amylase activity & GATCTCCTCCTITTCCT & GATCTGGAAGCGCGCCATTG & 25 & 25 & 5 & 5 \\
\hline & Glutelin & Os02g15070 & $\begin{array}{l}\text { Glutelin type-B } 7 \\
\text { precursor }\end{array}$ & GATCCATTGCACAAGAG & GATCCAGCCACAAACCAATG & 22 & 11 & 8 & 8 \\
\hline & Starch synthesis and degradation & Os06g51084 & $\begin{array}{l}\text { 1,4-alpha-glucan } \\
\text { branching enzyme, } \\
\text { chloroplast precursor }\end{array}$ & GATCAAGCAATGAATGC & GATCAACCCATGCTCCACCC & 24 & 24 & 19 & 19 \\
\hline & Seed specific & Os03g58480 & $\begin{array}{l}\text { Seed specific protein } \\
\text { Bn15D14A }\end{array}$ & GATCACATCGTCACAGC & GATCTAGAATCTCCAGAGGG & 14 & 28 & 7 & 7 \\
\hline & Starch degradation & Os02g32660 & $\begin{array}{l}\text { Expressed 1,4-alpha- } \\
\text { glucan branching } \\
\text { enzyme }\end{array}$ & GATCATGACTTTCAGCA & GATCACAGAAGACACACTTC & 6 & 24 & 8 & 8 \\
\hline & $\begin{array}{l}\text { Aspartate biosynthesis and } \\
\text { degradation II + asparagine } \\
\text { biosynthesis I and degradation I }\end{array}$ & Os02g14110 & $\begin{array}{l}\text { Nitrogen compound } \\
\text { metabolism }\end{array}$ & GATCTGTGAATTTGGCA & GATCCAGAGAGAGATGCTAA & 66 & 66 & 8 & 8 \\
\hline & Globulin & Os03g46100 & $\begin{array}{l}\text { Globulin-1 S allele } \\
\text { precursor }\end{array}$ & GATCATCCGCGCGTCGG & GATCGTTTAGTTGGGAGTGG & 20 & 20 & 8 & 8 \\
\hline & Seed maturation & Os09g10620 & $\begin{array}{l}\text { seed maturation protein } \\
\text { LEA } 4\end{array}$ & GATCGAGTTGAGTGTGT & GATCGACTTGTGTGAGTTGT & 16 & 16 & 8 & 8 \\
\hline \multirow[t]{9}{*}{$\begin{array}{l}\text { Up } \\
\text { regulated } \\
\text { in } \\
\text { Ilpumbyeo }\end{array}$} & Family & $\begin{array}{l}\text { TIGR Gene } \\
\text { ID }\end{array}$ & TIGR gene name & MPSS signature & SBS signature & $\begin{array}{l}\text { MPSS } \\
\text { Ratio } \\
\text { PSI/PSY }\end{array}$ & $\begin{array}{l}\text { MPSS } \\
\text { Ratio } \\
\text { PSI/PSN }\end{array}$ & $\begin{array}{l}\text { SBS Ratio } \\
\text { PSIO2/ } \\
\text { PSY02 }\end{array}$ & $\begin{array}{l}\text { SBS Ratio } \\
\text { PSIO2/ } \\
\text { PSN02 }\end{array}$ \\
\hline & Methionine degradation I & Os01g22010 & $\begin{array}{l}\text { Methionine } \\
\text { adenosyltransferase }\end{array}$ & GATCCCGACTTCACATG & GATCCTCGCGGCCGAAATGG & 35 & 35 & 14 & 14 \\
\hline & Isoleucine biosynthesis I & Os03g21080 & Acetolactate synthase & GATCGGAGCCTAGTTGC & GATCCAGCACACATTCAAAA & 5 & 5 & 10 & 10 \\
\hline & Starch synthesis & Os06g12450 & $\begin{array}{l}\text { Soluble starch synthase } \\
2-3 \text {, chloroplast precursor }\end{array}$ & GATCTGGAAGTGAAATA & GATCTGGAAGTGAAATATTT & 12 & 12 & 20 & 20 \\
\hline & Seed allergenic/lectin & Os07g11510 & $\begin{array}{l}\text { Seed allergenic protein } \\
\text { RA5 precursor }\end{array}$ & GATCGCCTCGCACCTGC & GATCACTTTAGTCTITATAG & 15 & 15 & 24 & 24 \\
\hline & Starch degradation & Os02g32660 & $\begin{array}{l}\text { Expressed 1,4-alpha- } \\
\text { glucan branching } \\
\text { enzyme }\end{array}$ & GATCAGTGTTTTAAGTT & GATCAAATTACATATTGCTG & 24.5 & 49 & 56 & 56 \\
\hline & Starch synthesis & Os06g04200 & $\begin{array}{l}\text { Granule-bound starch } \\
\text { synthase 1, chloroplast } \\
\text { precursor }\end{array}$ & GATCTTCCACAGCAACA & GATCTTGGCAAGTCAATTAA & 6 & 6 & 14 & 14 \\
\hline & Isoleucine degradation | & Os02g43720 & Enoyl-coA hydratase & GATCGTCTTGAAGGTCT & GATCTACCTCCATGCCTTGA & 6.2 & 25 & 15 & 15 \\
\hline & $\begin{array}{l}\text { Aspartate biosynthesis and } \\
\text { degradation II + asparagine } \\
\text { biosynthesis I and degradation I }\end{array}$ & Os01g55540 & Aspartate transaminase & GATCAAGTGGCTTTCAT & GATCGGCAAATACTCCTTAA & 34 & 34 & 32 & 32 \\
\hline
\end{tabular}




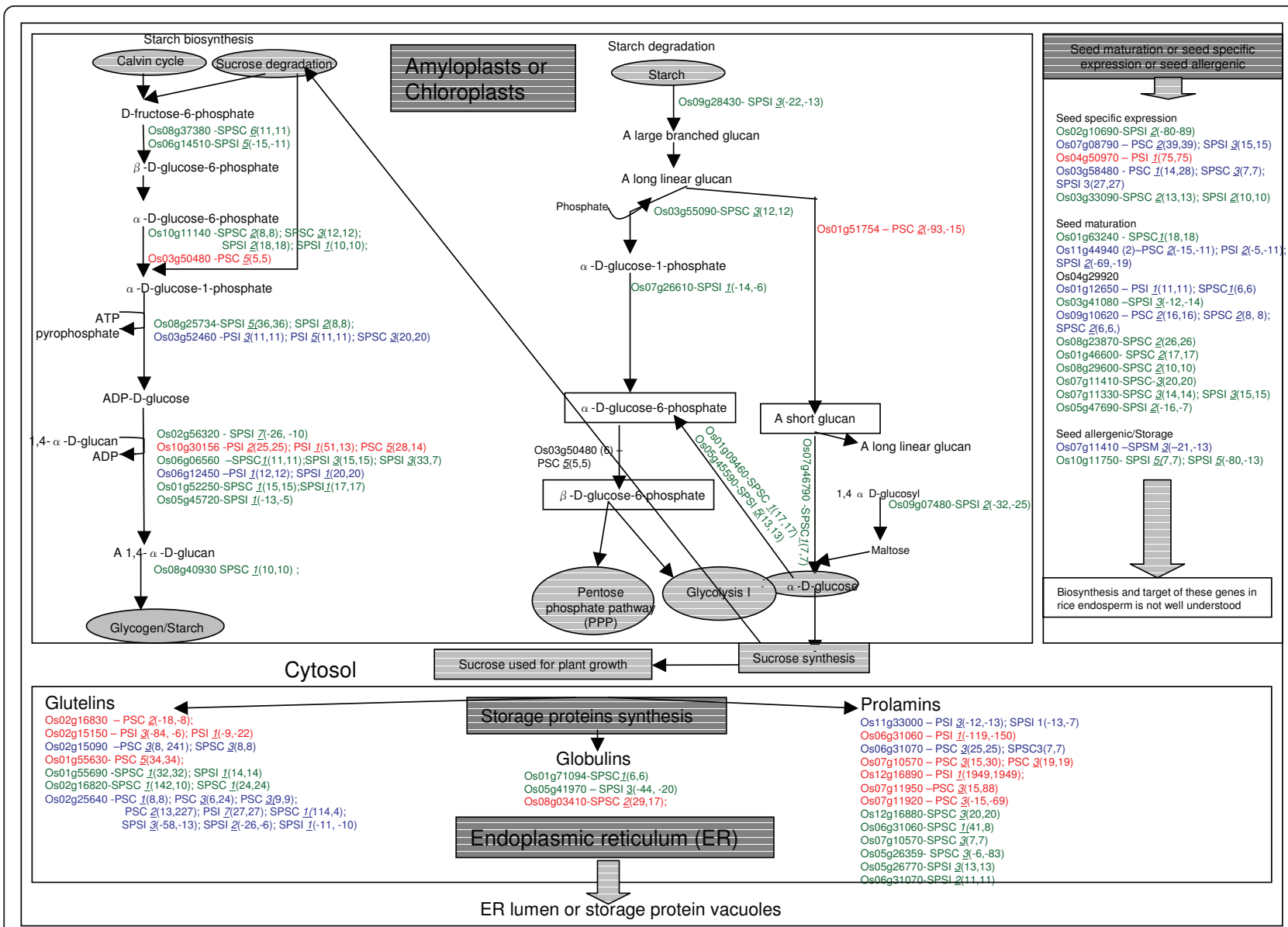

Figure 1 Network of genes involved in starch biosynthesis and degradation, and in the biosynthesis of seed storage, seed maturation, and allergenic proteins http://www.gramene.org. Only the genes with 5-fold up- or down-regulation in Cypress (PSC) or Ilpumbyeo (PSI) compared with that in LaGrue or YR15965 are shown. The positive number in parenthesis indicates up-regulation and the negative number in parenthesis indicates down-regulation. The first value in parenthesis shows the fold change in expression either in LaGrue or YR15965, and the second value shows the fold change in expression in Nipponbare. The italicized and underlined bold number before the parenthesis shows the MPSS/SBS signature class [45]. Green indicates that the gene was identified by SBS only. Red indicates that the gene was identified by MPSS only. Blue indicates that the gene was identified by both MPSS and SBS.

$4 \mathrm{~B}, 4 \mathrm{C})$. In addition, many of the genes involved in the amino acid biosynthesis also underwent alternative splicing. Among them, some showed 5-fold up-regulation in Ilpumbyeo in either the MPSS or SBS libraries, and these included genes encoding L-3-cyanoalanine synthase (Os04g08350), methionine gamma-lyase (Os09g28050), and asparaginase (Os04g46370), which showed two, two, and three alternative splice forms, respectively (Additional File 4A, 4B, 4C).

\section{Genes encoding seed-storage proteins}

The major classes of storage proteins are glutelins, globulins, and prolamins. Some of the genes encoding these classes showed over 5-fold up-regulation in Cypress compared to LaGrue and Nipponbare, and these genes included those encoding glutelin type-B7 precursors (Os02g15070, Os02g15090), globulin-1 S allele precursor (Os03g46100), prolamin PPROL 17 precursor (Os06g31070), and $13 \mathrm{kDa}$ prolamin precursor (Os07g10570) (Table 4 and Additional File 4A). Among the storage-protein genes with over 5 -fold up-regulation in Cypress, some produced antisense transcripts like those encoding glutelin type-B7 precursor (Os02g15070, Os02g15090), prolamin PPROL 17 precursor (Os06g31070), and $13 \mathrm{kDa}$ prolamin precursor (Os07g 10570) (Additional File 4A). Many genes encoding glutelins and prolamins also underwent alternative splicing or termination in Cypress and Ilpumbyeo. The gene encoding glutelin type-A 2 (Os02g25640) produced 15 and 17 alternative splice forms in MPSS and SBS libraries, and most of them were up-regulated in Cypress but down-regulated in Ilpumbyeo. Among the prolamin-related genes, the prolamin precursor protein gene (Os07g10570) produced five and six alternative splice forms in MPSS and SBS libraries, respectively. The 5 -fold induced or suppressed genes encoding globulin, prolamin, and glutelin storage proteins 


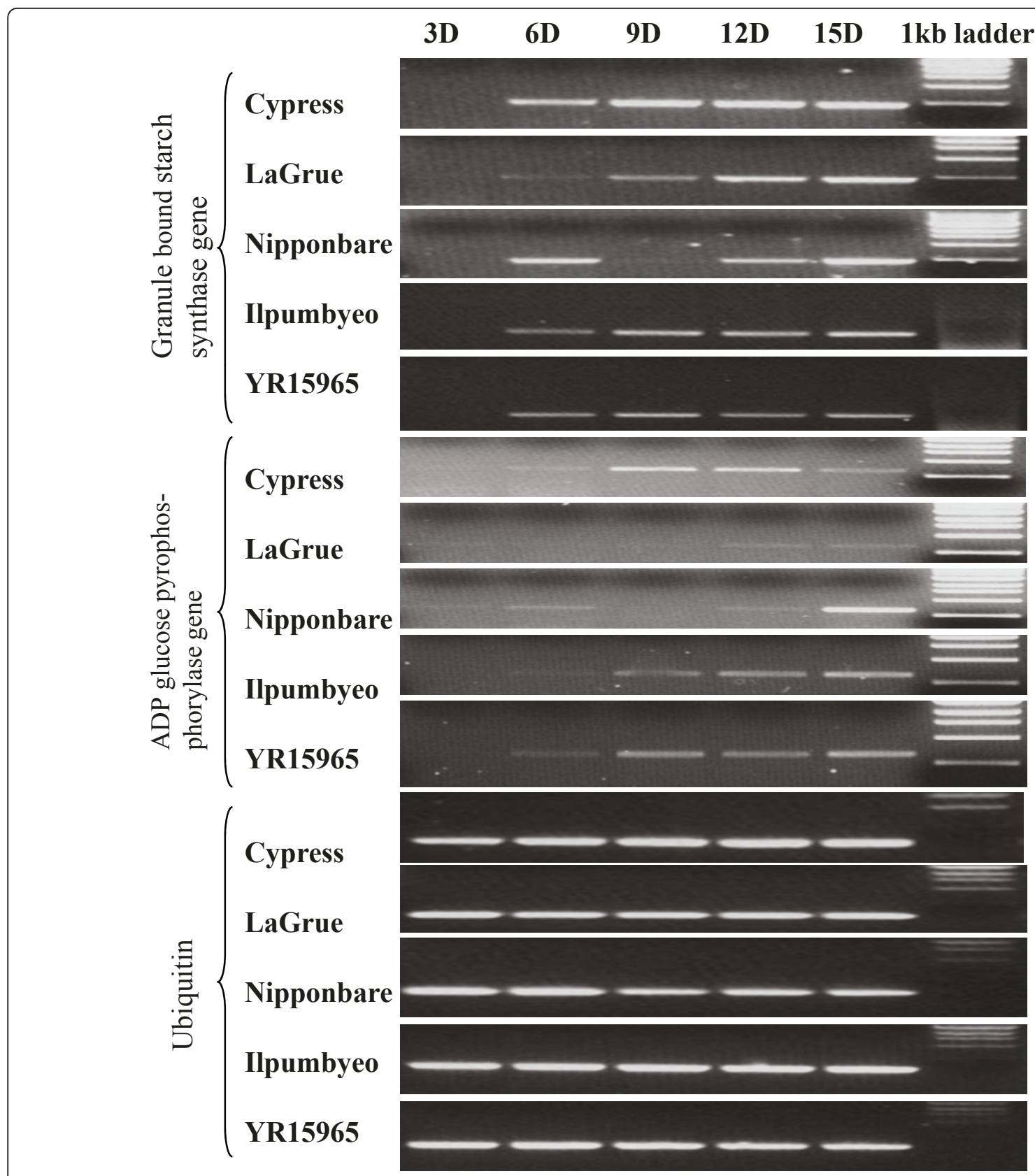

Figure 2 RT-PCR analysis of the genes encoding GBSS I and AGPase in developing rice seeds at 3, 6, 9, 12, and 15 days after anthesis in five rice cultivars

either in Cypress or Ilpumbyeo or both are listed in Additional File 4A and in Figure 1.

\section{Genes encoding seed maturation and allergenic and seed-} specific expression proteins

Some of the genes belonging to this group showed similar expression patterns in both MPSS and SBS libraries (Table 4 and Additional File 4A). For example, the genes encoding seed-specific protein Bn15D14A (Os03g58480) and seed-maturation protein LEA4 (Os09g10620) were > 5-fold up-regulated in Cypress compared to LaGrue and
Nipponbare in both MPSS and SBS libraries. However, the seed-allergenic protein RA5 precursor gene (Os07g11510) was up-regulated 15-fold in Ilpumbyeo compared to YR15965 (Table 4; Additional File 4A).

Expression patterns of TF genes in cultivars with high milling and good eating quality

TFs were identified using homology search in the rice TF database http://plntfdb.bio.uni-potsdam.de/v3.0/. Clustering analysis was performed to identify TF genes 
up- and down-regulated in Cypress and Ilpumbyeo compared to the controls (Table 3; Additional File 6). A total of 37 and 14 TF genes showed 5-fold up-regulation in Cypress and Ilpumbyeo libraries, respectively, in both SBS and MPSS libraries (Additional File 6). Similarly, 50 and 5 TF genes were down-regulated in Cypress and Ilpumbyeo, respectively, in both libraries. Some TFs were specifically up-regulated in either Cypress or Ilpumbyeo compared to the controls in both libraries. These TF genes encode PHD-finger family protein (PHD family; Os01g65600), zinc finger $\mathrm{CCCH}$ type domain containing protein ZFN-like 2 ( $\mathrm{C} 3 \mathrm{H}$ family; Os01g68860), transfactor (G2-like; Os06g40710), and bZIP transcription factor family protein (bZIP family; Os06g45140) (Additional File 6).

\section{Identification of the conserved cis motifs among the up- regulated genes in cultivars with high milling and good eating quality}

The promoter sequences (1.0 kb before the ATG site) of the highly up-regulated genes ( $\geq 50$-fold) in Cypress (compared to LaGrue and Nipponbare) and Ilpumbyeo (compared to YR15965 and Nipponbare) identified in both SBS and MPSS libraries were analyzed using the 'PLACE Signal Scan Search' software http://www.dna.affrc.go.jp/htdocs/ PLACE/. Many conserved motifs were present in the upregulated genes in Cypress and Ilpumbyeo, and these included CAATBOX1, WRKY71OS, GATABOX, EBOXB NNAPA, SEF4MOTIFGM7S, CGACGOSAMY3, WBOX HVISO1, CAREOSREP1, CANBNNAPA, AMYBOX1, AACACOREOSGLUB1, BOXIIPCCHS, 2SSEEDPROTBANAPA, ACGTABOX, AMYBOX2, ACGTCBOX, ACGTOSGLUB1, CEREGLUBOX2PSLEGA, and GAD OWNAT (Additional File 7). Interestingly, many of the motifs have been reported to play a role in seed development and germination (Additional File 7) [46-70].

\section{Discussion}

Rice is a major source of nutrition for most people in the developing world. Although tremendous achievements have been made for the improvement of many agronomic traits in rice in the last three decades, much less progress has been obtained for quality traits due to the lack of simple and efficient selection methods in rice breeding. With rapid advancement in crop molecular breeding, marker-aided selection has been successfully applied in many crop plants. Similarly, new methods for genetic engineering of better crop plants have been reported in the last decade by overexpressing or gene silencing of candidate genes. Although several eating quality QTLs have been identified in previous studies $[18,19]$, it is not clear whether these QTLs are useful for marker-aided selection or not because the genomic regions of these QTLs have not been further characterized. Recently
Nelson et al. [9] identified six main-effect milling yield QTLs in the two RIL populations derived from crosses of common parent Cypress with RT0034, a low-milling yield japonica line and LaGrue, a low-milling yield japonica cultivar, respectively. In this study, we used two high throughput sequencing technologies to profile the transcriptome of five cultivars differing in milling yield and eating quality. Many genes specifically or commonly expressed in the high milling yield cultivar Cypress and the good eating quality cultivar Ilpumbyeo were identified from the MPSS and SBS libraries. These candidate genes are excellent starting materials for the development of molecular markers linked to milling quality in the US and eating quality in Korea for rice breeding. It is also possible that overexpression or silencing of some candidate genes will lead to the generation of transgenic rice plants with superior grain quality.

During the rice seed development, sugars, amino acids, and other important metabolites are transported from source (primarily leaves) to sink (seeds). Once in the seeds, these metabolites are allocated to different biosynthetic pathways (primarily starch metabolism and storage protein biosynthesis) to produce mainly starch and proteins in precise quantities and ratios. Achieving such a defined composition of starch and proteins require the regulation and coordination of various pathways so that, at each developmental stage, the participating enzymes are present in appropriate amounts and in the correct cellular compartments [3]. AGPase and GBSS I play important roles during starch biosynthesis in rice [71]. The genes encoding for AGPase and GBSS I enzymes are highly expressed 7 to 28 days after flowering during grain development, and their expression is highly correlated with the increases in both starch content and grain weight. The AGPase gene is also highly expressed in the high-yield cultivars of both glutinous and non-glutinous rice [71]. In addition, AGPase (Os01g44220) undergoes alternative splicing similar to the AGPase small subunit gene in barley [72]. Duan and Sun [3] showed that a mutation in the GBSS I gene leads to a lower level of functional GBSS I mRNA and correspondingly to a lower level of GBSS I enzyme for amylose synthesis, which causes a reduction in amylose accumulation. During rice seed formation, the genes encoding AGPases are active 3 days before flowering and maintain an intermediate although declining level of activity during seed maturation [3]. Genetic variation survey showed that the polymorphism in the rice waxy gene encoding the GBSS enzyme explains much of the variation in apparent amylose content across 92 important long, medium and short grain US rice cultivars and 101 progeny of a cross between low-amylose and intermediate-amylose breeding lines $[73,74]$. The amylose content and the level of waxy protein in 31 rice cultivars 
from China were correlated with the ability of the cultivar to excise intron I from the leader sequence of the Wx transcript [75]. In this study, we found that the important starch biosynthesis related genes encoding AGPase (Os01g44220), 1,4- $\alpha$-glucan branching enzyme (Os02g32660), limit dextrinase (Os04g08270), 1,4- $\alpha$-glucan branching enzyme (Os06g51084), and $\alpha$-amylase (Os09g29404) were up-regulated in Cypress compared to LaGrue and Nipponbare in six-days old developing seeds. Our time-course RT-PCR analysis also confirmed that expression of AGPase and GBSS I genes was higher in the high milling cultivar Cypress than in the low milling cultivar LaGrue early (6 and 9 DAF) in seed development. These results suggest that these two genes related to starch synthesis may greatly affect milling yield. Starch biosynthesis is also associated with complex genotypic-environmental interactions in maize endosperm [76]. Since the plants in this study were grown in the controlled environmental conditions (growth chambers), the effect of environmental factors on the expression of the starch biosynthesis genes should be tested in the field conditions.

Cereal proteins are generally deficient in lysine, but lysine content might be increased with increased accumulation of the precursor molecules required for the enzymatic reactions involved in lysine metabolism. The key precursor molecules include lactate, acetyl CoA, malate, L-aspartate, L-asparagine, L-aspartate-semialdehyde, homoserine, homocysteine, 2 -oxobutanoate, 2 -aceto-1hydroxybutyrate, and $\alpha$-ketoglutarate, and the enzymes involved in their production are very important (Additional File 5). Enhancing the production of these precursor molecules will require the identification of the genes encoding these enzymes. In this study, we found that the genes encoding malate dehydrogenase (Os03g56280, Os01g46070) and aminotransferase (Os09g28050, Os03 g18810) involved in the production of malate and aspartate in Cypress and Ilpumbyeo, respectively, were up-regulated compared to the controls. Genes encoding aspartate transaminase (Os01g55540) and enoyl-CoA hydratase (Os02g43720) enzymes, which are responsible for the production of acetyl CoA, were also up-regulated in Cypress compared to the controls. Similarly, the gene encoding lactoylglutathione lyase (Os05g07940), which is responsible for the production of lactate, was up-regulated in Cypress compared to the controls. As indicated, genetic manipulation of the expression levels of these precursors/ enzymes may lead to an increased accumulation of lysine in the endosperm and thus an increased nutritional value of the rice seeds.

In the last decade, oligoarrays, SAGE, MPSS, and SBS have been widely used for transcriptome profiling. MPSS and SBS have been recently used for whole-genome transcription analysis and have generated abundant expression data for many organisms $[42,44,45]$. In this study, both MPSS and SBS technologies were used to analyze the transcriptomes of the 6-days-old developing seeds in five rice cultivars. The number of redundant and non-redundant signatures generated in this study were similar to those in previous reports in rice and Arabidopsis $[43,45,77]$. Although MPSS generates large volume of data, its complicated library-construction procedure and high sequencing cost limit its use in individual laboratories. As the cost of the next-generation sequencing methods has significantly decreased in the last few years, SBS sequencing has become a popular method for transcriptome analysis because it costs $90 \%$ less than MPSS and can generate at least three times more transcripts. Furthermore, in the current study, about 30\% more transcripts were found in the SBS library than in the MPSS library. Many of these additional signatures are low-copy transcripts, indicating that SBS is a powerful method for identifying rare transcripts [43]. The correlation coefficient is higher between MPSS and SBS than between RL-SAGE and microarray [78], or between RL-SAGE and MPSS or MPSS and microarrays as in previous studies [79]. Therefore, SBS will undoubtedly become the preferred high throughput sequencing method for deep transcriptome analysis in plants.

\section{Conclusion}

Breeding for milling yield and eating quality in rice has been a daunting task due to the low genetic inheritability of both traits and the lack of molecular markers linked to the phenotypes. Genetic mapping of the two traits is also challenging because the traits are easily affected by environmental factors in the field. Using two high throughput sequencing methods, we identified many differentially expressed genes in developing rice seeds that may affect milling yield or eating quality. Many of the identified genes are involved in the biosynthesis of starch, aspartate family amino acids, and storage proteins. Some of these potential candidate genes could be used for the development of molecular markers for breeding programs or for the engineering of rice cultivars with high milling yield and eating quality. Our study provides a valuable genomic resource for both improvement of rice grain quality and for the characterization of grain quality pathways at the molecular and biochemical levels.

\section{Methods}

Plant materials, developing seeds harvest and growth conditions

Five rice cultivars including Cypress, LaGrue, Ilpumbyeo, YR15965, and Nipponbare were used in the study. Cypress (japonica cultivar) is a long grain cultivar with high yield and high milling quality released by Louisiana 
State University. Cypress dries down slowly in the field, avoiding grain fissuring, cracking and chalkiness that reduce milling quality http://agebb.missouri.edu/rice/ research/99/pg5.htm[80-84]. LaGrue (japonica cultivar), a long grain variety released by the University of Arkansas in 1993, has low milling quality [80-84]. Both Cypress and LaGrue seeds were provided by Dr. Robert Fjellstrom, USDA-ARS Dale Bumpers National Rice Research Center, Stuttgart, Arkansas, USA. Ilpumbyeo (japonica cultivar) is a good eating quality cultivar with low amylose content [85-87]. YR15965 (japonica cultivar) is a low eating quality rice, derived from a cross between Hwayeongbyeo (temperate japonica variety) and Shennung 89-366 (sub-tropical japonica) [86]. Both Ilpumbyeo and YR15965 seeds were provided by Dr. Gynheung An, Crop Biotech Institute, Kyung Hee University, Korea. Nipponbare (japonica cultivar) was used as a control for milling and eating quality with Cypress, LaGrue, Ilpumbyeo and YR15965. All the five cultivars were grown in 3 replications in a Conviron growth chamber at $80 \%$ relative humidity with $12 \mathrm{~h}$ of light $(500 \mu \mathrm{mol}$ photons $\mathrm{m}-2 \mathrm{sec}-1)$ at $26^{\circ} \mathrm{C}$ followed by $12 \mathrm{~h}$ of dark at $20^{\circ} \mathrm{C}$. The spikelets were labeled on the day of anthesis to identify the age of developing seeds in a panicle. The developing seeds were harvested from the panicles at 3, 6, 9, 12 and $15 \mathrm{D}$ after anthesis. The excised developing seeds from the panicle were freezed immediately in liquid nitrogen.

\section{RNA isolation and RT-PCR}

Total RNA was isolated from developing rice seeds harvested from Cypress, LaGrue, Ilpumbyeo, YR15965 and Nipponbare plants using Trizol reagent (Invitrogen). For removal of polysaccharides/polyglycons from the extract, the extracted RNA was purified twice by high salt precipitation according to the manufacturer's instructions. For the MPSS and SBS library construction, RNA isolated from the 6-days (D)-old developing seeds (intermediate stage of grain filling) was used. For the timecourse RT-PCR validation experiments, RNA isolated at 3, 6, 9, 12 and 15 D old developing seeds was used. RTPCR was performed as described previously [78].

\section{MPSS and SBS library construction, sequencing, and bioinformatics}

MPSS and SBS libraries were constructed using the RNA obtained from 6 days old developing seeds from Cypress (MPSS library-PSC; SBS library-SPSC), LaGrue (MPSS library-PSL; SBS library-SPSL), Ilpumbyeo (MPSS library-PSI; SBS library-SPSI), YR15965 (MPSS library PSY; SBS library-SPSY) and Nipponbare (MPSS libraryPSN; SBS library-SPSN). MPSS and SBS library construction and sequencing were performed essentially as previously described $[43,45,77]$. Data analysis was carried out to identify the genes responsible for milling quality and eating quality. The expression profiles of Cypress were compared with that of LaGrue and Nipponbare to identify the genes responsible for milling quality. Similarly, the expression profiles of Ilpumbyeo were compared with that of YR15965 and Nipponbare to identify the genes responsible for eating quality. Bioinformatic analyses including identification of antisense transcripts, alternate transcripts, and TFs were conducted as previously described [43]. Gramene database http://www. gramene.org was used as a reference database for the identification of genes involved in starch metabolism, aspartate amino acid metabolism, storage and allergenic protein synthesis, and seed maturation [88]. The entire dataset is available at the NCBI's Gene Expression Omnibus (GEO) database through the accession number GSM629225 to GSM629233

\section{Additional material}

\begin{abstract}
Additional file 1: Filter results of the five MPSS and SBS libraries. A) A total of 39,288 distinct 17-base expressed signatures from the five MPSS libraries were processed according to three filters: significance, reliability, and genomic match. B) Similarly, 397,543 signatures from the five SBS libraries were also processed using these same filters as previously described by Meyers et al. [45].

Additional file 2: Classification of the MPSS and SBS signatures from the five libraries based on their location on the annotated gene (hits = 1) (See Meyers et al. 2004 [45]for details).

Additional file 3 : List of expressed grain quality related genes identified in 6 days old developing seeds by MPSS and SBS technologies

Additional file 4: List of five fold up and down-regulated genes, antisense and alternate transcripts. A: List of genes commonly identified by MPSS and SBS technologies. Five fold up- and downregulated genes, antisense and alternate transcripts are presented. B: Genes identified by SBS technology. Five fold up- and down-regulated genes, antisense and alternate transcripts are listed. C: Genes identified by MPSS technology. Five fold up- and down-regulated genes, antisense and alternate transcripts are listed.
\end{abstract}

Additional file 5: Network of lysine and aspartate family amino acid biosynthesis and degradation. http://www.gramene.org. Only the genes with 5-fold up- or down-regulation in Cypress (PSC) or Ilpumbyeo (PSI) compared with that in LaGrue or YR15965 are shown. The positive number in parenthesis indicates up-regulation and the negative number in parenthesis indicates down-regulation. The first value in parenthesis shows the fold change in expression either in LaGrue or YR15965, and the second value shows the fold change in expression in Nipponbare. The italicized and underlined bold number before the parenthesis shows the MPSS/SBS signature class [45]. Green indicates that the gene was identified by SBS only. Red indicates that the gene was identified by MPSS only. Blue indicates that the gene was identified by both MPSS and SBS.

Additional file 6: Five fold up and down regulated transcription factors identified by MPSS, SBS and both

Additional file 7: Conserved cis elements in the promoter region of the highly induced genes ( $\geq 50$ fold) in Cypress (compared to LaGrue and Nipponbare) and Ilpumbyeo (compared to YR15965 and Nipponbare) that are involved in seed development. 


\section{Acknowledgements}

This work was supported by US National Science Foundation grants (\#0321437 and 0701745) to B.C.M. and G.L.W, a USDA RiceCAP grant to G.L. W. and funding from Kyung Hee University to G.A.

\section{Author details}

'Department of Plant Pathology, The Ohio State University, Columbus OH43210, USA. 'Delaware Biotechnology Institute, University of Delaware, Newark DE-19711, USA. ${ }^{3}$ Crop Biotech Institute, Kyung Hee University, Youngin 446-701, Republic of Korea. ${ }^{4}$ State Key Laboratory for Biology of Plant Diseases and Insect Pests, Institute of Plant Protection, Chinese Academy of Agricultural Sciences, Beijing, 100193, China.

\section{Authors' contributions}

RCV and MVS grew the plants, collected developing seeds, extracted RNA and performed RTPCR experiments, constructed SBS libraries, bioinformatic analysis of MPSS and SBS data and wrote the manuscript, KN and AB analyzed the data, GA, BCM and G-LW designed the experimental plan and revised the manuscript. The authors agreed on the contents of the paper.

Received: 4 October 2010 Accepted: 14 April 2011

Published: 14 April 2011

\section{References}

1. Juliano BO: Rice in human nutrition. FAO Food and Nutrition Series, No. 26 Publication Division. FAO of the United Nations, Rome; 1993, 35-84.

2. Wang Z, Gu YJ, Chen G, Xiong F, Li YX: Rice quality and its affecting factors. Mol Plant Breeding 2003, 1:231-241.

3. Duan M, Sun SS: Profiling the expression of genes controlling rice grain quality. Plant Mol Biol 2005, 59(1):165-78.

4. van Ruiten HTL: Rice milling: an overview. In Rice: chemistry and technology.. 2 edition. Edited by: Juliano BO. The American Association of Cereal Chemists, St. Paul; 1985:349-388.

5. Webb BD: Criteria of rice quality in the United States. In Rice: Chemistry and Technology. 2 edition. Edited by: Juliano BO. The American Association of Cereal Chemists, St. Paul; 1985:403-442.

6. Siebenmorgen TJ, Meullenet JF: Impact of drying, storage, and milling of rice quality and functionality. In Rice: chemistry and technology.. 3 edition. Edited by: Champagne ET. The American Association of Cereal Chemists, St. Paul; 2004:301-328.

7. Zheng TQ, XU JL, Li ZK, Zhai HQ, Wan JM: Genomic regions associated with milling quality and grain shape identified in a set of random introgression lines of rice (Oryza sativa L.). Plant Breed 2007, 126:158-163.

8. Kepiro JL, McClung AM, Chen MH, Yeater KM, Fjellstrom RG: Mapping QTLs for milling yield and grain characteristics in a tropical japonica long grain cross. J Cereal Sci 2008, 48:477-485.

9. Nelson JC, McClung AM, Fjellstrom RG, Moldenhauer KAK, Boza E, Jodari F, Oard JH, Linscombe S, Scheffler BE, Yeater KM: Mapping QTL main and interaction influences on milling quality in elite US rice germplasm. Theor Appl Genet 2011, 122:291-309.

10. Juliano BO, Onate LU, Mundo AM: Relation of starch composition, protein content, and gelatinization temperature to cooking and eating qualities of milled rice. Food Technol 1965, 19:1006-1011.

11. Ishima T, Taira H, Taira H, Mikoshiba K: Effect of nitrogenous fertilizer application and protein content in milled rice on organleptic quality of cooked rice. Rep Nat Food Res Inst 1974, 29:9-15.

12. Juliano BO: A simplified assay for milled-rice amylose. Cereal Sci Today $1971,16: 334-340$.

13. Juliano BO: The rice caryopsis and its composition. In Rice: Chemistry and Technology. Edited by: Houston DF. American Assoc. Cereal Chemists Inc. St. Paul; 1985:17-74.

14. Liu W, Zeng J, Jiang G, He Y: QTLs identification of crude fat content in brown rice and its genetic basis analysis using $\mathrm{DH}$ and two backcross populations. Euphytica 2009, 169(2):197-205.

15. Cagampang GB, Perez CM, Juliano BO: A gel consistency test for the eating quality of rice. J Sci Food Agric 1973, 24:1589-1594.

16. Bao JS, Sun M, Corke H: Analysis of genetic behavior of some starch properties in indica rice (Oryza sativa L.): thermal properties, gel texture, swelling volume. Theor Appl Genet 2002, 104:408-413.

17. Yano M, Sasaki T: Genetic and molecular dissection of quantitative traits in rice. Plant Mol Biol 1997, 35:145-153.
18. Wan XY, Wan JM, Su CC, Wang CM, Shen WB, Li JM, Wang HL, Jiang L, Liu SJ, Chen LM, et al: QTL detection for eating quality of cooked rice in a population of chromosome segment substitution lines. Theor Appl Genet 2004, 110:71-79.

19. Hao W, Zhu MZ, Gao JP, Sun $S Y$, Lin $H X$ : Identification of quantitative trait loci for rice quality in a population of chromosome segment substitution lines. J Integr Plant Biol 2009, 51(5):500-12.

20. Cho YC, Hong HC, Sub JP, Jeong YP, Choi IS, Kim MK, Kim YG, Choi HC, Hwang HG: QTL mapping for grain quality and shape in japonica $\times$ javanica in rice. Korean J Breeding 2004, 36(1):408-409.

21. Tan YF, Li JX, Yu SB, Xing YZ, Xu CG, Zhang QF: The three important traits for cooking and eating qualities of rice grain are controlled by a single locus. Theor Appl Genet 1999, 99:642-648.

22. Septiningsih EM, Trijatmiko KR, Moeljopawiro S, McCouch SR: Identification of quantitative trait loci for grain quality in an advanced backcross population derived from the Oryza sativa variety IR64 and the wild relative O. rufipogon. Theor Appl Genet 2003, 107:1433-1441.

23. Zhou PH, Tan YF, He YQ, Xu CG, Zhang Q: Simultaneous improvement for four quality traits of Zhenshan 97 , an elite parent of hybrid rice, by molecular marker-assisted selection. Theor Appl Genet 2003, 106:326-331.

24. Ordonez SA, Silva J, Oard JH: Association mapping of grain quality and flowering time in elite japonica rice germplasm. J Cereal Sci 2010, 51:337-343.

25. Li ZF, Wan JM, Xia JF, Zhai HQ, Ikehashi H: Identification of quantitative trait loci underlying milling quality of rice (Oryza sativa) grains. Plant Breeding 2004, 123:229-234.

26. Tan YF, Sun M, Xing YZ, Hua JP, Sun XL, Zhang QF, Corke H: Mapping quantitative trait loci for milling quality, protein content and color characteristics of rice using a recombinant inbred line population derived from an elite rice hybrid. Theor Appl Genet 2001, 103:1037-1045.

27. Mei H, Luo L, Guo L, Wang Y, Yu X, Ying C, Li Z: Molecular mapping of QTLs for rice milling yield traits. Acta Genet Sin 2002, 29:791-797.

28. Aluko G, Martinez C, Tohme J, Castano C, Bergman C, Oard JH: QTL mapping of grain quality traits from the interspecific cross Oryza sativa $\times$ O. glaberrima. Theor Appl Genet 2004, 109:630-639.

29. Dong $Y$, Tsuzuki $E$, Lin D, Kamiunten $H$, Terao $H$, Matsuo M, Cheng S: Molecular genetic mapping of quantitative trait loci for milling quality in rice (Oryza sativa L.). J Cereal Sci 2004, 40(2):109-114.

30. Jiang GH, Hong XY, Xu CG, Li XH, He YQ: Identification of Quantitative Trait Loci for Grain Appearance and Milling Quality Using a DoubledHaploid Rice Population. J Integr Plant Biol 2005, 47(11):1391-1403.

31. Lou J, Chen L, Yue G, Lou Q, Mei H, Xiong L, Luo L: QTL mapping of grain quality traits in rice. J Cereal Sci 2009, 50:145-151.

32. Ball SG, van de Wal MHBJ, Visser RGF: Progress in understanding the biosynthesis of amylose. Trends Plant Sci 1998, 3:462-467.

33. Myers AM, Morell MK, James MG, Ball SG: Recent progress towards understanding biosynthesis of the amylopectin crystal. Plant Physiol 2000, 122:989-997.

34. James MG, Denyer K, Myers AM: Starch synthesis in the cereal endosperm. Curr Opin Plant Biol 2003, 6:215-222.

35. Kim WT, Li X, Okita TW: Expression of storage protein multigene families in developing rice. Plant Cell Phyisol 1993, 34:595-603.

36. Muntz K: Deposition of storage protein. Plant Mol Biol 1998, 38:77-99

37. Choi SB, Wang C, Muench DG, Ozawa K, Franceschi VR, Wu L, Okita TW: Messenger RNA targeting of rice seed storage proteins to specific ER subdomains. Nature 2000, 407:765-767.

38. Shewry PR, Halford NG: Cereal seed storage proteins: structures, properties and role in grain utilization. J Exp Bot 2002, 53:947-958.

39. Zhou ZK, Robards K, Helliwell S, Blanchard C: Composition and functional properties of rice. Intl J Food Technol 2002, 37:849-868

40. Azevedo RA, Arruda P, Turner WL, Lea PJ: The biosynthesis and metabolism of the aspartate derived amino acids in higher plants. Phytochem 1997, 46:395-419.

41. Tian Z, Qian Q, Liu Q, Yan M, Liu X, Yan C, Liu G, Gao Z, Tang S, Zeng D, Wang Y, Yu J, Gu M, Li J: Allelic diversities in rice starch biosynthesis lead to a diverse array of rice eating and cooking qualities. Proc Natl Acad Sci, USA 2009, 106(51):21760-21765.

42. Vega-Sanchez ME, Gowda M, Wang G-L: Tag-based approaches for deep transcriptome analysis in plants. Plant Science 2007, 173:371-380.

43. Venu RC, Sheshu Madhav M, Sreerekha MV, Nobuta K, Zhang Y, Carswell P, Boehm MJ, Meyers BC, Korth KL, Wang G-L: Deep and Comparative 
Transcriptome Analysis of Rice Plants Infested by the Beet Armyworm (Spodoptera exigua) and Water Weevil (Lissorhoptrus oryzophilus). Rice 2010, 3:22-35.

44. Simon SA, Zhai J, Nandety RS, McCormick, et al: Short-Read Sequencing Technologies for Transcriptional Analyses. Annu Rev Plant Biol 2009, 60:305-33.

45. Meyers BC, Tej SS, Vu TH, Haudenschild CD, Agrawal V, Edberg SB, et al: The use of MPSS for whole-genome transcriptional analysis in Arabidopsis. Genome Res 2004, 14:1641-53.

46. Shirsat A, Wilford N, Croy R, Boulter D: Sequences responsible for the tissue specific promoter activity of a pea legumin gene in tobacco. Mol Gen Genet 1989, 215:326-331.

47. Rogers HJ, Bate N, Combe J, Sullivan J, Sweetman J, Swan C, Lonsdale DM, Twell D: Functional analysis of cis-regulatory elements within the promoter of the tobacco late pollen gene g10. Plant Mol Biol 2001, 45:577-585.

48. Zhang ZL, Xie Z, Zou X, Casaretto J, Ho TH, Shen QJ: A rice WRKY gene encodes a transcriptional repressor of the gibberellin signaling pathway in aleurone cells. Plant Physiol 2004, 134:1500-1513.

49. Rubio-Somoza I, Martinez M, Abraham Z, Diaz I, Carbonero P: Ternary complex formation between HvMYBS3 and other factors involved in transcriptional control in barley seeds. Plant J 2006, 47:269-281.

50. Stalberg K, Ellerstom M, Ezcurra I, Ablov S, Rask L: Disruption of an overlapping E-box/ABRE motif abolished high transcription of the napA storage-protein promoter in transgenic Brassica napus seeds. Planta 1996, 199:515-519.

51. Filichkin SA, Leonard JM, Monteros A, Liu PP, Nonogaki H: A novel endobeta-mannanase gene in tomato LeMAN5 is associated with anther and pollen development. Plant Physiol 2004, 134:1080-1087.

52. O'Neill SD, Kumagai MH, Majumdar A, Huang N, Sutliff TD, Rodriguez RL: The alpha-amylase genes in Oryza sativa: Characterization of CDNA clones and mRNA expression during seed germination. Mol Gen Genet 1990, 221:235-244

53. Lessard PA, Allen RD, Bernier F, Crispino JD, Fujiwara T, Beachy RN: Multiple nuclear factors interact with upstream sequences of differentially regulated beta-conglycinin genes. Plant Mol Biol 1991, 16:397-413.

54. Hwang YS, Karrer EE, Thomas BR, Chen L, Rodriguez RL: Three cis-elements required for rice alpha-amylase Amy3D expression during sugar starvation. Plant Mol Biol 1998, 36:331-341

55. Sun C, Palmqvist $\mathrm{S}$, Olsson $\mathrm{H}$, Boren $\mathrm{M}$, Ahlandsberg $\mathrm{S}$, Jansson C: A nove WRKY transcription factor, SUSIBA2, participates in sugar signaling in barley by binding to the sugar-responsive elements of the iso1 promoter. Plant Cell 2003, 15:2076-2092

56. Nakashima K, Fujita Y, Katsura K, Maruyama K, Narusaka Y, Seki M, Shinozaki RAK, Yamaguchi-Shinozaki K: Transcriptional regulation of ABI3and ABA-responsive genes including RD29B and RD29A in seeds, germinating embryos, and seedlings of Arabidopsis. Plant Mol Biol 2006, 60:51-68.

57. Thomas MS, Flavell RB: Identification of an enhancer element for the endosperm-specific expression of high molecular weight glutenin. Plant Cell 1990, 2:1171-1180

58. Sutoh K, Yamauchi D: Two cis-acting elements necessary and sufficient for gibberellin-upregulated proteinase expression in rice seeds. Plant $J$ 2003, 34:635-645.

59. Ellerstrom M, Stalberg K, Ezcurra I, Rask L: Functional dissection of a napin gene promoter: identification of promoter elements required for embryo and endosperm-specific transcription. Plant Mol Biol 1996, 32:1019-1027.

60. Huang N, Sutliff TD, Litts JC, Rodriguez RL: Classification and characterization of the rice alpha-amylase multigene family. Plant $\mathrm{Mo}$ Biol 1990, 14:655-668.

61. Wu C, Washida H, Onodera Y, Harada K, Takaiwa F: Quantitative nature of the Prolamin-box, ACGT and AACA motifs in a rice glutelin gene promoter: minimal cis-element requirements for endosperm-specific gene expression. Plant J 2000, 23:415-421

62. Nakashima K, Fujita Y, Katsura K, Maruyama K, Narusaka Y, Seki M, Shinozaki K, Yamaguchi-Shinozaki K: Transcriptional regulation of ABI3and ABA-responsive genes including RD29B and RD29A in seeds, germinating embryos, and seedlings of Arabidopsis. Plant Mol Biol 2006 60:51-68.
63. Stalberg K, Ellerstom M, Ezcurra I, Ablov S, Rask L: Disruption of an overlapping E-box/ABRE motif abolished high transcription of the napA storage-protein promoter in transgenic Brassica napus seeds. Planta 1996, 199:515-519.

64. Izawa T, Foster R, Nakajima M, Shimamoto K, Chua N-H: The rice bZIP transcriptional activator RITA-1 is highly expressed during seed development. Plant Cell 1994, 6:1277-1287.

65. Huang N, Sutliff TD, Litts JC, Rodriguez RL: Classification and characterization of the rice alpha-amylase multigene family. Plant $\mathrm{Mol}$ Biol 1990, 14:655-668.

66. Forde BG, Heyworth A, Pywell J, Kreis M: Nucleotide sequence of a B1 hordein gene and the identification of possible upstream regulatory elements in endosperm storage protein genes from barley, wheat and maize. Nucleic Acids Res 1985, 13:7327-7339.

67. Izawa T, Foster R, Nakajima M, Shimamoto K, Chua N-H: The rice bZIP transcriptional activator RITA-1 is highly expressed during seed development. Plant Cell 1994, 6:1277-1287.

68. Washida H, Wu CY, Suzuki A, Yamanouchi U, Akihama T, Harada K, Takaiwa F: Identification of cis-regulatory elements required for endosperm expression of the rice storage protein glutelin gene GluB-1. Plant Mol Biol 1999, 40:1-12.

69. Shirsat A, Wilford N, Croy R, Boulter D: Sequences responsible for the tissue specific promoter activity of a pea legumin gene in tobacco. Mol Gen Genet 1989, 215:326-331.

70. Ogawa M, Hanada A, Yamauchi Y, Kuwahara A, Kamiya Y, Yamaguchi S: Gibberellin biosynthesis and response during Arabidopsis seed germination. Plant Cell 2003, 15:1591-1604.

71. Hwang JW, Kim SK, Lee JS, Kim IS: Gene expression of the biosynthetic enzymes and biosynthesis of starch during Rice Grain development. J Plant Biol 2005, 48(4):448-455

72. Thorbjornsen T, Villand P, Kleczkowski LA, Olsen OA: A single gene encodes two different transcripts for the ADP-glucose pyrophosphorylase small subunit from barley (Hordeum vulgare). Biochem J 1996, 313(1):149-154

73. Ayres NM, McClung AM, Larkin PD, Bligh HFJ, Jones CA, Park WD: Microsatellites and a single-nucleotide polymorphism differentiate apparent amylose classes in an extended pedigree of US rice germplasm. Theor Appl Genet 1997, 04:773-781.

74. Bergman CJ, Fjellstrom R, McClung A: Association between amylose content and a microsatellite across exotic rice germplasm. International Rice Genetics Symposium. 4 edition. IRRI: Manila, The Philippines; 2001.

75. Wang ZY, Zheng FQ, Shen GZ, Gao JP, Snustad DP, Li MG, Zhang JL, Hong MM: The amylose content in rice endosperm is related to the post-transcriptional regulation of the waxy gene. Plant J 1995, 7(4):613-22.

76. Fergason VL, Zuber MS: Influence of environments on amylose content of maize endosperm. Crop Sci 1962, 6:209.

77. Nobuta K, Venu RC, Lu C, Belo A, Vemaraju K, Kulkarni K, et al: An expression atlas of rice mRNAs and small RNAs. Nature Biotechnol 2007 25:473-7.

78. Venu RC, Jia Y, Gowda M, Jia MH, Jantasuriyarat C, Stahlberg E, et al: RLSAGE and microarray analysis of the rice transcriptome after Rhizoctonia solani infection. Mol Genet Genomics 2007, 278:421-31.

79. Gowda M, Venu RC, Raghupathy MB, Nobuta K, Li H, Stahlberg E, et al Deep and comparative analysis of the mycelium and appressorium transcriptomes of Magnaporthe grisea using MPSS, RL-SAGE, and oligoarray methods. BMC Genomics 2006, 8(7):310.

80. Counce PA, Bryant RJ, Bergman CJ, Bautista RC, Wang YA, Siebenmorgen TJ, Moldenhauer KK, Meullenet JC: Rice Milling Quality, Grain Dimensions, and Starch Branching as Affected by High Night Temperatures. Cereal Chem 2005, 82(6):645-648.

81. Fan J, Siebenmorgen TJ, Yang W: A study of head rice yield reduction of long- and medium-grain rice varieties in relation to various harvest and drying conditions. Transactions of the ASAE 2000, 43(6):1709-1714.

82. Kepiro JL, Fjellstrom RG, McClung AM: Studying the inheritance of high milling yield in Cypress. Texas Rice, Highlighting Research in 2006 VIIIX.

83. Kumar R, Qiu J, Joshi T, Valliyodan B, Xu D, Nguyen HT: Single Feature Polymorphism Discovery in Rice. PLOS ONE 2007, 2(3):e284.

84. Oard JH, Moldenhauer KK, Fjellstrom RG, Nelson J, Linscombe SD, Silva J, May GD: Registration of the MY2 Cypress/LaGrue rice recombinant 
inbred line mapping population. Journal of Plant Registrations 2010,

4(3):1-5.

85. Kim KS, Kang HJ, Hwang IK, Hwang HG, Kim TY, Choi HC: Comparative ultrastructure of Ilpumbyeo, a high-quality japonica rice, and its mutant, Suweon 464: scanning and transmission electron microscopy studies. J Agric Food Chem 2004, 52(12):3876-83.

86. Lee JS, Ha WG, Chang JK, Ryu KL, Cho JH, Song YC, Kwon OK, Yang SJ, Kim HY, Suh HS: QTL Analysis for Grain Quality Properties in a Japonica Rice Combination. New directions for a diverse planet. Proceedings of the 4th International Crop Science Congress, Brisbane, Australia, $26 \mathrm{Sep}-1$ Oct 2004 .

87. Kim KS, Hwang HG, Kang HJ, Hwang IK, Lee YT, Choi HC: Ultrastructure of individual and compound starch granules in isolation preparation from a high-quality, low-amylose rice, ilpumbyeo, and its mutant, G2, a highdietary fiber, high-amylose rice. J Agric Food Chem 2005, 53(22):8745-51.

88. Ware DH, Jaiswal P, Ni J, Yap IV, Pan X, Clark KY, Teytelman L, Schmidt SC, Zhao W, Chang K, Cartinhour S, Stein LD, McCouch SR: Gramene, a tool for grass genomics. Plant Physiol 2002, 130(4):1606-13.

doi:10.1186/1471-2164-12-190

Cite this article as: Venu et al:: Deep sequencing reveals the complex and coordinated transcriptional regulation of genes related to grain quality in rice cultivars. BMC Genomics 2011 12:190.

\section{Submit your next manuscript to BioMed Central} and take full advantage of:

- Convenient online submission

- Thorough peer review

- No space constraints or color figure charges

- Immediate publication on acceptance

- Inclusion in PubMed, CAS, Scopus and Google Scholar

- Research which is freely available for redistribution

Submit your manuscript at www.biomedcentral.com/submit 